\title{
ANALISIS PENCAPAIAN KOMPETENSI MAHASISWA PRAKTIK PROFESI NERS DI STIKES HANG TUAH PEKANBARU
}

\author{
Isis Miniati ${ }^{1}$, Raja Fitrina Lestari ${ }^{2}$, Lita $^{3}$ \\ Program Studi Sarjana Keperawatan STIKes Hang Tuah Pekanbaru \\ isisminiati03@gmail.com¹, rajafitrinalestari@htp.ac.id ${ }^{2}, \underline{\text { lita@htp.ac.id }}$
}

\begin{abstract}
Competence is a sufficient ability to do certain things in order to achieve what is expected. It is also the knowledge and skills possessed by every individual applied in thinking and behaving where he/she can perform the real quality in carrying out a task and job. The objective of this research was to find out The Analysis of Competency Achievement of Professional Nursing Students. This research was a quantitative research with Retrospective research design. It was conducted from January to September, 2020 at Bachelor Nursing Study Program of Institute of Health Sciences (STIKES) of Hang Tuah Pekanbaru. The population of this research was the Professional Nursing Students. The samples were taken by using total sampling consisted 36 students. The researcher used the questionnaire as the instrument of the research. Results showed that there were 8 respondents (22.2\%) with sufficient competency achievement, while 28 respondents (77.8\%) had good competency achievement. It can be concluded that the Competency Achievement of Professional Nursing Students of STIKes Hang Tuah Pekanbaru is in "Good" category. There were three actions mostly could not achieved by the students, namely giving Oxygen, preparing Pre-Operative client, and inserting NGT. Hence, by this result, the Professional Nursing Students are expected to be able to increase the assignment of Competency Achievement.
\end{abstract}

Keywords $\quad$ : Competence, Nursing Students, Nursing Profession

\begin{abstract}
ABSTRAK
Kompetensi merupakan kemampuan yang cukup untuk melakukan sesuatu tertentu agar tercapainya yang diharapkan, kompetensi juga merupakan pengetahuan dan keterampilan yang dimiliki oleh setiap individu yang diterapkan dalam berpikir dan bertingkah laku yang dimana individu akan menunjukkan kualitas yang sebenarnya dalam melaksanakan suatu tugas dan pekerjaannya. Penelitian ini bertujuan untuk mengetahui analisis pencapaian kompetensi mahasiswa praktik profesi Ners. Jenis penelitian ini adalah kuantitatif dengan desain penelitian retrospektif. Penelitian ini dimulai dari bulan Januari hingga September 2020 di Prodi Sarjana Keperawatan STIKes Hang Tuah Pekanbaru. Populasi dalam penelitian ini adalah mahasiswa profesi Ners dengan jumlah sampel 36 orang dengan total sampling. Alat ukur yang digunakan adalah kuesioner. Sebanyak 8 responden $(22.2 \%)$ pencapaian kompetensinya cukup, sedangkan 28 responden $(77,8 \%)$ pencapaian kompetensinya baik. Hal ini dapat disimpulkan bahwa pencapaian kompetensi pada mahasiswa praktik profesi Ners STIKes Hang Tuah Pekanbaru berada pada kategori baik. Terdapat tiga tindakan yang paling banyak tidak tercapai oleh mahasiswa yaitu memberikan O2, melakukan persiapan klien pre op, dan memasang NGT. Hasil penelitian ini diharapkan mahasiswa profesi Ners agar dapat meningkatkan penugasan pencapaian kompetensi.
\end{abstract}

Kata Kunci : Kompetensi, Mahasiswa Ners, Profesi Ners

\section{PENDAHULUAN}

Praktik profesi Ners merupakan jenjang lanjutan bagi Mahasiswa Sarjana (S1) keperawatan. Dalam menjalankan profesi Ners ini mahasiswa menerapkan keseluruhan ilmu yang telah di dapat selama menempuh proses pendidikan S1 dalam suatu bentuk tindakan asuhan keperawatan bagi pasien dilapangan. Praktik profesi Ners menjadi suatu keharusan bagi seluruh mahasiswa S1 keperawatan yang akan melaksanakan 
praktik keperawatan, tanpa memiliki gelar Ners, kesempatan menjadi perawat akan tertutup, oleh karena itu mahasiswa praktik profesi Ners melakukan praktik selama 1 tahun di rumah sakit pendidikan (UndangUndang Keperawatan, 2014).

Menurut Peraturan Pemerintah Republik Indonesia Nomor 93 Tahun (2015) tentang Rumah Sakit Pendidikan dalam pasal 1 menyebutkan bahwa Rumah Sakit pendidikan adalah Rumah Sakit yang mempunyai fungsi sebagai tempat pendidikan, penelitian, dan pelayanan kesehatan secara terpadu di bidang pendidikan kedokteran atau kedokteran gigi, pendidikan berkelanjutan, dan pendidikan kesehatan lainnya secara multiprofesi.

Di Indonesia Rumah Sakit pendidikan berjumlah 24 dan 6 yang beroperasi sebagai rumah sakit pendidikan, sedangkan di Provinsi Riau memiliki 1 Rumah Sakit pendidikan yaitu RSUD Arifin Achmad Provinsi Riau. Berdasarkan Renstra Kementrian Kesehatan 2015-2019 menyatakan bahwa untuk meningkatkan pelayanan kesehatan di Rumah Sakit (RS) masih menghadapi kendala kekurangan tenaga kesehatan terutama tenaga keperawatan di RS, sehubungan dengan hal itu, jumlah Program Studi (Prodi) Kesehatan di Perguruan Tinggi (PT), masing-masing sebanyak 719 Perguruan Tinggi Negri (PTN), 2.624 Perguruan Tinggi Swasta (PTS), 463 Perguruan Tinggi Kementrian/ Lembaga lain (PTK), dan 34 Perguruan Tinggi Agama (PTA). Sehingga total keseluruhan berjumlah 3.840. Institusi pendidikan adalah perguruan tinggi yang menyelenggarakan pendidikan akademik, profesi, dan/atau profesi di bidang kedokteran, kedokteran gigi, dan/atau tenaga kesehatan seperti gizi, farmasi, rekam medis terutama tenaga kesehatan.

Keperawatan menurut Peraturan Pemerintah Republik Indonesia Nomor 93 Tahun (2015). Pendidikan klinik merupakan inti dalam pendidikan keperawatan. Pendidikan klinik bagi mahasiswa adalah cara belajar mengaplikasikan teori ke dalam dunia kerja yang nyata. Pendidikan klinik yang efektif mampu membangun rasa percaya diri mahasiswa dan membantu pencapaian kompetensi klinik dengan bimbingan dari preseptor akademik maupun preseptor klinik saat melakukan praktik klinik. Kompetensi merupakan perpaduan dari pengetahuan, keterampilan, nilai dan sikap yang direfleksikan dalam kebiasaan berpikir dan bertindak dalam praktik kerja lapangan (Mulyasa, 2010).

Praktik Kerja Lapangan (PKL) merupakan kegiatan belajar yang melibatkan mahasiswa secara aktif di dalam prosesnya. Kegiatan PKL dirancang untuk memberikan pengalaman praktis kepada mahasiswa dalam menggunakan metodologi yang relevan untuk menganalisis keadaan, identifikasi masalah, dan menetapkan alternatif solusi. Selain itu, mahasiswa diberikan kesempatan untuk mengaplikasikan kemampuan memecahkan masalah, berpikir kritis, komunikasi efektif, dan kemampuan motorik (keterampilan) yang diperoleh selama pembelajaran di kelas. Kegiatan pembelajaran di lahan praktik dirancang berdasarkan garis-garis besar mata ajar, sehingga mahasiswa mendapatkan pengalaman belajar praktik di tatanan yang nyata secara benar dan terarah untuk pencapaian kompetensi yang telah diisyaratkan dalam kurikulum (Kementerian Kesehatan Republik Indonesia Edisi 1 Tahun 2017).

Menurut Jejen Musfa (2011) mengatakan kompetensi terkait dengan kemampuan beradaptasi terhadap lingkungan kerja baru, dimana seseorang dapat menjalankan tugasnya dengan baik berdasarkan kemampuan yang dimilikinya. Sedangkan menurut penelitian Muhammad Ramadhan (2019) kompetensi merupakan kemampuan yang cukup untuk melakukan suatu tertentu agar tercapainya yang diharapkan, kompetensi ini juga merupakan pengetahuan dan keterampilan yang dimiliki oleh setiap individu yang diterapkan dalam berpikir dan bertingkah 
laku yang dimana individu akan menunjukkan kualitas yang sebenarnya dalam melaksanakan suatu tugas dan pekerjaannya.

Menurut buku paduan Ners Keperawatan Anak (2019/2020) target untuk tercapainya sebuah pencapaian kompetensi agar hasil belajar yang didapatkan pada pembelajaran adalah $80 \%$ yang mampu melakukan pengelolaan bahan belajarnya. Dalam proses ini dosen bertanggung jawab untuk membuat mudahnya interaksi mahasiswa dengan lingkungan belajarnya. Terdapat banyak pendekatan pendidikan untuk pencapaian kompetensi, salah satunya adalah dengan menggunakan modul atau menggunakan teknologi (IT). Dengan modul pembelajaran dapat menjadikan mahasiswa tidak tergantung pada kehadiran dosen dan menjadi efektif bagi mahasiswa maupun bagi dosen dalam mencapai kompetensi kemampuan mengelola kasus pasien (Ngesti, 2018).

Menurut penelitian terkait Ngesti (2018), mahasiswa D3 Keperawatan Malang yang sedang menempuh pendidikan keperawatan semester V. Pencapaian kompetensi mahasiswa keperawatan melalui metode pembelajaran bedside teaching dengan menggunakan fasilitas modul pembelajaran yang telah disusun oleh dosen, yang berisikan kasuskasus sesuai dengan teori aplikatif dengan kasus yang ada di klinik Rumah Sakit. Dalam penelitian ini hasil pelaksanaan ujian kompetensi diasumsikan sebagai hasil pembelajaran bedside teaching dan penugasan mahasiswa keperawatan yang menggunakan fasilitas modul praktek klinik berisikan kasus yang sering ditemui di Rumah Sakit tempat praktek mahasiswa.

Hasil survey awal pendahuluan yang telah dilakukan dengan cara wawancara ke mahasiswa profesi Ners STIKes Hang Tuah Pekanbaru yang berjumlah 36 Mahasiswa di gerbong mata kuliah Keperawatan Anak Tahun Ajaran 2019/2020 dengan 4 SKS yang berjumlah 28 butir kompetensi dalam waktu dinas selama 5 minggu diruangan
Lili, Edelweis, Thalasemia, Neonatus, dan di Puskesmas. Pada saat pengumpulan kompetensi gelombang pertama hanya 15 mahasiswa dengan persentase terisi $19.4 \%$ sedangkan target yang akan dicapai adalah $80 \%$. Waktu di lakukan wawancara pada Koordinator mata kuliah Keperawatan Anak mengatakan belum semua mahasiswa mengumpulkan karena kondisi saat dilapangan beberapa mahasiswa harus menemui preseptor kliniknya untuk memintai tanda tangan serta waktu untuk melengkapi penugasan kompetensi tersebut. Pada saat di lakukan wawancara ke beberapa mahasiswa pendidikan profesi Ners yang berjumlah 10 mahasiswa mengatakan cara pengisian kompetensi ada dengan cara setiap hari, dan ada juga yang mengisi setiap minggu disaat pergantian ruangan atau di isi disaat pertemuan dengan preseptor klinik. Berdasarkan kondisi dilapangan mahasiswa profesi Ners mengatakan tidak sesuainya pekerjaan klinik dilapangan dengan kasus yang di berikan, hal tersebut membuat mahasiswa profesi Ners kesulitan untuk mengisi butir kasus pada kompetensi. Berdasarkan latar belakang diatas, maka peneliti tertarik untuk melakukan penelitian analisis pencapaian kompetensi mahasiswa praktik profesi Ners di STIKes Hang Tuah Pekanbaru.

\section{METODE}

Jenis penelitian ini adalah kuantitatif dengan desain penelitian retrospektif. Populasi penelitian adalah seluruh mahasiswa praktik profesi Ners STIKes Hang Tuah Pekanbaru berjumlah 36 responden. Pengambilan sampel menggunakan probability sampling dengan simple random sampling dan alat pengumpulan data menggunakan lembar kuesioner.

\section{HASIL}

Karakteristik Responden

Tabel 1. Distribusi Frekuensi Berdasarkan 
Karakteristik Responden Mahasiswa Profesi Ners di STIKes Hang Tuah Pekanbaru Tahun 2019/2020

\begin{tabular}{lcc}
\hline Frekuensi & n & $\begin{array}{c}\text { Persentase } \\
(\%)\end{array}$ \\
\hline $\begin{array}{l}\text { Jenis Kelamin } \\
\text { - Laki-Laki }\end{array}$ & 8 & 22,2 \\
Perempuam menurut & 28 & 77,8 \\
\hline Usia & & \\
Departemen & \\
Kesehatan Republik & & \\
Indonesia & 32 & 88,9 \\
a. Masa remaja & & \\
$\quad \begin{array}{l}\text { Akhir = 17-25 } \\
\text { tahun (usia 23 }\end{array}$ & & \\
tahun ada & 3 & 8,3 \\
direntang ini) \\
b. Masa remaja \\
$\quad$ Akhir = 17-25 & 1 & \\
\hline
\end{tabular}

\begin{tabular}{lll}
\hline tahun $(24$ tahun & & \\
ada direntang ini) & & \\
c. Masa dewasa & & \\
Awal $=26-35$ & & \\
tahun (usia 27 & & \\
tahun ada & & \\
direntang ini) & & 200 \\
\hline total & 72 & \\
\hline
\end{tabular}

Berdasarkan tabel 1 diatas dapat diketahui bahwa dari 36 responden yang diteliti, distribusi frekuensi sebagian besar responden berjenis kelamin perempuaan sebanyak 28 prang $(77,8 \%)$, sedangkan mayoritas usia adalah adalah 23 tahun $(88,9 \%)$.

\section{Pencapaian Kompetensi}

Tebel 2. Distribusi Frekuensi Pencapaian Kompetensi

\begin{tabular}{|c|c|c|c|c|c|}
\hline \multirow[t]{2}{*}{ No. } & \multirow[t]{2}{*}{ Pertanyaan } & \multicolumn{2}{|c|}{ Tercapai } & \multicolumn{2}{|r|}{ Tercapai } \\
\hline & & $\mathbf{N}$ & $\%$ & $\mathbf{N}$ & $\%$ \\
\hline 1. & Memandikan klien ditempat tidur & 36 & 100 & 0 & 0 \\
\hline 2. & Memberikan obat melalui IV & 36 & 100 & 0 & 0 \\
\hline 3. & Perawatan luka & 36 & 100 & 0 & 0 \\
\hline 4. & Memasang infus & 36 & 100 & 0 & 0 \\
\hline 5. & Melakukan oral hygiene & 36 & 100 & 0 & 0 \\
\hline 6. & Nebulizer & 36 & 100 & 0 & 0 \\
\hline 7. & Memberikan O2 & 35 & 97,2 & 1 & 2,8 \\
\hline 8. & Melakukan persiapan klien pre op & 35 & 97,2 & 1 & 2,8 \\
\hline 9. & Memasang NGT & 35 & 97,2 & 1 & 2,8 \\
\hline 10. & Melakukan MTBS & 35 & 97,2 & 1 & 2,8 \\
\hline 11. & Pemasangan NGT/OGT & 35 & 97,2 & 1 & 2,8 \\
\hline 12. & Melakukan suction & 34 & 94,4 & 2 & 5,6 \\
\hline 13. & Pengambilan spesimen darah vena & 34 & 94,4 & 2 & 5,6 \\
\hline 14. & Melakukan DDST & 34 & 94,4 & 2 & 5,6 \\
\hline 15 . & Melakukan penkes & 34 & 94,4 & 2 & 5,6 \\
\hline 16. & Perawatan bayi inkubator & 34 & 94,4 & 2 & 5,6 \\
\hline 17. & Memberikan obat melalui IM & 33 & 91,7 & 3 & 8,3 \\
\hline 18. & Melakukan stimulasi tumbang & 33 & 91,7 & 3 & 8,3 \\
\hline 19. & Memandikan bayi & 32 & 88,9 & 4 & 11,1 \\
\hline 20. & Memberikan obat melalui SC & 32 & 88,9 & 4 & 11,1 \\
\hline 21. & Melakukan perawatan colostomi & 32 & 88,9 & 4 & 11,1 \\
\hline 22. & Pengambilan spesimen darah arteri & 28 & 77,8 & 8 & 22,2 \\
\hline 23. & Memberikan obat Intratekal & 27 & 75 & 9 & 25 \\
\hline 24. & Melakukan tapid water sponge & 27 & 75 & 9 & 25 \\
\hline 25. & Melakukan resusitasi anak/neonatus & 26 & 72,2 & 10 & 27,8 \\
\hline 26. & Imunisasi & 16 & 44,4 & 20 & 55,6 \\
\hline 27. & Mantoux test & 13 & 36,1 & 23 & 63,9 \\
\hline 28. & Lumbal Punksi & 10 & 27,8 & 26 & 72,2 \\
\hline
\end{tabular}

Berdasarkan tabel 2 dapat diketahui bahwa syarat kriteria evaluasi penilaian untuk pencapaian kompetensi dengan metode evaluasi psikomotor yang terbagi menjadi dua, yang pertama capaian kompetensi dengan bobot $(15 \%)$ dengan waktu pelaksanaan $(80 \%)$ tindakan mandiri selama praktik (dinilai oleh koordinator 
stase). Kedua Direct Observasional of Preocedure Skill (DOPS) dengan bobot $(10 \%)$ dengan waktu pelaksanaan 1 kali selama praktik (minggu ke lima). Kriteria penilaian mahasiswa profesi keperawatan anak dinyatakan lulus dengan mekanisme yaitu memenuhi kehadiran (100\%). Kriteria penilaian pencapaian kompetensi yaitu secara mandiri, asisten dan observasi.



Berdasarkan tabel 3 dapat diketahui bahwa dari 36 responden yang diteliti, Distribusi Frekuensi Berdasarkan Kategori Pencapian Kompetensi didapatkan mayoritas berada pada kategori baik sebanyak 28 orang $(77,8 \%)$.

\section{PEMBAHASAN}

\section{Karakteristik Responden Jenis Kelamin}

Dari hasil penelitian didapatkan jumlah responden sebagian besar berjenis kelamin perempuan sebanyak 28 orang $(77,8 \%)$. Sesuai dengan data yang peneliti dapatkan di Prodi Sarjana Keperawatan STIKes Hang Tuah Pekanbaru bahwa mahasiswa perempuan lebih banyak dari laki-laki. Hasil penelitian yang dilakukan oleh Mohamad Judha (2019) yang menyatakan bahwa perempuan lebih banyak lulus dari pada laki-laki, akan tetapi kelulusan kompetensi tidak ditentukan oleh jenis kelamin. Budiawan (2015) menjelaskan bahwa laki-laki memiliki dorongan lebih besar dari pada wanita karena tanggung jawab laki-laki lebih besar dari pada perempuan. Perbedaan biologis dan fungsi biologis antara laki-laki dan perempuan tidak dapat dipertukarkan di antara keduanya, Perbedaan fungsi biologis inilah yang menyebabkan antara laki-laki dan perempuan memiliki peran dan tanggung jawab yang berbeda

Menurut Mauidlotul Alifah (2017) Proses perkembangan, mahasiswa telah memasuki fase remaja akhir dan dewasa awal yang tidak hanya menuntut untuk meningkatkan kualitas pengetahuan saja, tetapi keterampilan dan kualitas pribadi sebagai bekal hidup mandiri. Mahasiswa remaja akhir dan dewasa awal memiliki motivasi untuk belajar lebih tinggi. Selain itu, mahasiswa remaja akhir dan dewasa awal merupakan masa kerja yang produktif.

Berdasarkan uraian diatas pencapaian kompetensi bisa tercapai oleh jenis kelamin perempuan maupun laki-laki, akan tetapi laki-laki dan perempuan memiliki banyak perbedaan khususnya dalam segi psikologisnya. Laki-laki memiliki kemampuan pemecahan masalah yang lebih baik dari pada perempuan. Laki-laki juga dapat bersikap lebih tenang dalam menghadapi suatu permasalahan, lebih menggunakan pemikiran dari pada emosi dalam melakukan suatu tindakan.

\section{Usia}

Berdasarkan hasil penelitian didapatkan bahwa sebagian besar responden berada pada usia 23 tahun sebanyak 32 orang (88,9\%). Menurut Departemen Kesehatan Republik Indonesia (2009) menyatakan bahwa Masa remaja Akhir berada pada rentang usia 1725 tahun, diantara rentang usia tersebut responden penelitian ada direntang usia 23-24 tahun. Pada Masa dewasa Awal berada pada rentang usia 26-35 tahun, diantara rentang usia tersebut responden penelitian ada direntang usia 27 tahun. Proses perkembangan, mahasiswa telah memasuki fase remaja akhir dan dewasa awal yang tidak hanya menuntut untuk meningkatkan kualitas pengetahuan saja, tetapi keterampilan dan kualitas pribadi sebagai bekal hidup mandiri. Mahasiswa 
remaja akhir dan dewasa awal memiliki motivasi untuk belajar lebih tinggi dari pada mahasiswa dewasa akhir karena mahasiswa dewasa akhir mempunyai beban hidup yang lain sehingga perhatiannya tidak hanya untuk belajar. Selain itu, mahasiswa remaja akhir dan dewasa awal merupakan masa kerja yang produktif.

Viantika (2017) menyebutkan bahwasannya usia tidak menjadi faktor pengganggu dalam penelitian ini karena proporsi usia mahasiswa di setiap tempat pembelajaran relatif sama. Usia terkait dengan kedewasaan dalam melakukan pekerjaan maupun kematangan psikologisnya, semakin lanjut usia seseorang maka semakin meningkat kematangan psikologisnya dan kedewasaan dalam menyelesaikan pekerjaan. Menurut penelitian Setyaningsih (2016), usia dewasa awal merupakan usia yang matang dalam psikologis. Seseorang yang berada pada usia dewasa awal akan lebih berorientasi pada tugas dari pada ego pribadi, yang berarti pada usia ini individu memiliki kemampuan bertanggung dalam pekerjaan yang tinggi.

Berdasarkan uraian diatas usia juga mempengaruhi kemampuan individu seseorang, yang berada pada usia dewasa awal akan lebih berorientasi pada tugas dari pada ego pribadi, yang berarti pada usia ini individu memiliki kemampuan bertanggung dalam pekerjaan yang tinggi.

\section{Pencapaian Kompetensi}

Berdasarkan hasil penelitian yang didapatkan pada gerbong keperawatan anak bahwa terdapat kategori baik sebanyak 28 orang $(77,8 \%)$ dan kategori cukup sebanyak 8 orang $(22,2 \%)$. Pencapaian kompetensi mahasiswa praktik profesi Ners menunjukkan bahwa sebagian besar mahasiswa dapat mencapai target kompetensi kliniknya dengan baik, akan tetapi ada butir kompetensi yang paling banyak tidak tercapai oleh mahasiswa yaitu Lumbal Punksi sebanyak 26 orang
$(72,2 \%)$, Mantoux test sebanyak 23 orang $(63,9 \%)$, Imunisasi sebanyak 20 orang (55,6\%), Melakukan resusitasi anak/neonatus sebanyak 10 orang $(27,8 \%)$, Melakukan tapid water sponge sebanyak 9 orang $(25 \%)$, memberikan obat Intratekal sebanyak 9 orang (25\%), Pengambilan spesimen darah arteri sebanyak 8 orang $(22,2 \%)$, Melakukan perawatan colostomi sebanyak 4 orang $(11,1 \%)$, Memberikan obat melalui SC sebanyak 4 orang $(11,1 \%)$, Memandikan bayi sebanyak 4 orang (11,1\%), Melakukan stimulasi tumbang sebanyak 3 orang $(8,3 \%)$, Memberikan obat melalui IM sebanyak 3 orang $(8,3 \%)$, Perawatan bayi inkubator sebanyak 2 orang $(5,6 \%)$, Melakukan penkes sebanyak 2 orang $(5,6 \%)$, Melakukan DDST sebanyak 2 orang $(5,6 \%)$, Pengambilan spesimen darah vena sebanyak 2 orang $(5,6 \%)$, Melakukan suction sebanyak 2 orang (5,6\%), Pemasangan NGT/OGT sebanyak 1 orang (2,8\%), Melakukan MTBS sebanyak 1 orang $(2,8 \%)$, Memasang NGT sebanyak 1 orang $(2,8 \%)$, Melakukan persiapan klien pre op sebanyak 1 orang $(2,8 \%)$, Memberikan O2 sebanyak 1 orang $(2,8 \%)$. Tidak tercapainya butir kompetensi tersebut disebabkan karena mahasiswa jarang mendapatkan tindakan tersebut dan bisa disebabkan oleh mahasiswa kurang memahami tindakan tersebut.

Lain halnya dengan penelitian Setyobudi (2013) menyebutkan bahwasannya sebagaian besar mahasiswa dapat mencapai kompetensinya tentang penilaian GCS dikarenakan metode yang digunakan sesuai dengan kebutuhan pembelajaran mahasiswa sehingga kompetensinya dapat tercapai. Hal ini berbeda dengan penelitian lainnya yang menyebutkan bahwa mahasiswa keperawatan merasa tidak berkompeten dalam melakukan tindakan praktik dikarenakan mahasiswa merasa cemas untuk melakukan kesalahan tindakan dan adanya kesenjangan teori dalam pengaplikasian tindakan praktiknya. Pencapaian kompetensi dapat dipengaruhi 
oleh beberapa faktor yaitu keterampilan, pengalaman, kepribadian, kondisi emosional, dan motivasi.

Sejalan dengan hasil penelitian Mauidlotul (2017) menunjukkan bahwa sebagian besar mahasiswa mempersepsikan pembimbing klinik dengan baik. Hal ini sejalan dengan penelitian yang dilakukan Sukesi (2013) menunjukkan bahwa mahasiswa mempersepsikan bimbingan yang diberikan oleh pembimbing klinik dalam kategori baik sebanyak (80\%). Persepsi bimbingan dalam kategori baik dikarenakan pembimbing klinik menggunakan metode yang sesuai dengan kebutuhan pembelajaran klinik mahasiswa. Berbeda dengan penelitian Adila (2015) menyebutkan bahwa pembimbing klinik kurang memberikan motivasi/dorongan, metode pembelajaran monoton, pemberian reinforcement kurang, perhatian pembimbing kurang, dan pembimbingan masih terkesan seadanya.

Hasil penelitian Dewanti (2016) menunjukkan bahwa pembimbing klinik dapat menciptakan pengalaman belajar yang positif bagi mahasiswa dan memberikan umpan balik yang terus berlanjut agar mahasiswa dapat mencapai kompetensinya. Penelitian ini menunjukkan bahwa pembimbing klinik yang memiliki kemampuan dalam mengajar, kompetensi keperawatan, evaluasi keperawatan, hubungan interpersonal dan kepribadian dapat mempengaruhi kompetensi klinik mahasiswa profesi Ners. Kemampuan pembimbing dalam mendemosntrasikan teknik dan prosedur klink memiliki nilai tertinggi dalam penelitian ini.

Pendemonstrasian prosedur klinik membuat mahasiswa cepat menangkap materi yang diajarkan dan dapat berlatih keterampilan klinik dengan dibawah pengawasan pembimbing, sehingga pengetahuan dan keterampilan mahasiswa akan meningkat. Hasil penelitian Sari, et al (2016) merekomendasikan model preseptor dalam pembelajaran klinis dapat meningkatkan pencapaian kompetensi siswa. Tes kompetensi adalah dilakukan untuk mengevaluasi pencapaian kompetensi siswa setelah berlatih pada tahap tertentu, pembelajaran klinis harus fokus pada pengetahuan, keterampilan dan sikap (Jamshidi, 2012)

Berdasarkan uraian diatas pencapaian kompetensi klinik mahasiswa tidak hanya dipengaruhi oleh pembimbing klinik, akan tetapi dapat dipengaruhi oleh faktor lain seperti metode pembelajaran, fasilitas/peralatan, konten materi, lingkungan pembelajaran, pengetahuan, keterampilan, sikap, pengalaman, pelatihan, dan motivasi. Pembimbing klinik menampilkan perannya secara maksimal, akan tetapi dari diri mahasiswanya tidak memiliki motivasi/dorongan untuk terus belajar juga dapat mempangaruhi tingkat pencapaian kompetensinya. Dorongan internal dapat meningkatkan semangatnya sehingga timbul keinginan kuat untuk mempelajari sesuatu, sehingga berdampak positif dalam meningkatkan pengetahuan serta keterampilan mahasiswa.

\section{KESIMPULAN}

Berdasarkan hasil penelitian yang dilakukan di Prodi Sarjana Keperawatan STIKes Hang Tuah Pekanbaru digerbong keperawatan anak tahun ajar 2019/2020, tentang Analisis Pencapaian Kompetensi Mahasiswa Parktik Profesi Ners di STIKes Hang Tuah Pekanbaru, dapat diambil kesimpulan sebagai berikut: kategori baik sebanyak 28 orang $(77,8 \%)$, dan kategori cukup sebanyak 8 orang $(22,2 \%)$.

\section{UCAPAN TERIMAKASIH}

Penelitian ini dapat dilaksanakan dengan baik berkat bantuan dari berbagai pihak, untuk itu penelitian mengucapkan terimakasih kepada dosen pembimbing yang telah membantu proses bimbingan, responden penelitian yang telah mengisi kuesioner dengan sejujurnya, serta serta 
beberapa pihak lainnya.

\section{DAFTAR PUSTAKA}

A, Aziz, Hidayat. (2011). Metode penelitian Keperawatan dan TeknikAnalisis Data. Jakarta: Salemba Medika.

Afriyanti Yati, Rahmawati.I.N.( 2014). Metodologi Penelitian Kualitatif dalam Riset Keperawatan. Raja Wali Pers, Jakarta.

AIPNI (2012). Pembinaan Internal Anggota AIPNI dalam Implementasi KBK Pendidikan Ners

AIPNI (2016) Kurikulum Inti Pendidikan Ners Indonesia 2015. Asosiasi Institusi Pendidikan Ners Indonesia.

Asosiasi Institusi Pendidikan Ners Indonesia (AIPNI) (2015). Kurikulum Inti Ners Indonesia. Cetakan Pertama.

Black,J. M., \& Hawks, J. H. (2014).Keperawatan Medikal Bedah: Manajemenklinis untuk Hasil yang Diharapkan. Edisi 8.Jakarta: Salemba Medika.

Budiono dan Pertami Sumira Budi. (2015). Konsep Dasar Keperawatan, Budi Medika, Jakarta.

Buku paduan Program Profesi Ners Keperawatan Anak (2019). Program Studi Ilmu Keperawatan STIKes Hang Tuah Pekanbaru.

Bungin, H.M Burhan. 2017. Metodologi Penelitian Kuantitatif : Komunikasi, Ekonomi, dan Kebijakan Public serta ilmu-ilmu lainnya. Edisi kedua. Jakarta. Penerbit : Kencana.

Dakir, H. 2010. Perencanaan dan pengembangan kurikulum. Jakarta : Rineka Cipta.

Departemen Kesehatan RI. UndangUndang Republik Indonesia Nomor 36 Tahun 2009 Tentang Kesehatan. Jakarta: Kementrian Kesehatan RI: 2009
Dewanti S, Suza DE, Nurhidayah RE. Hubungan kinerja instruktur klinis dengan pencapaian kompetensi klinik mahasiswa keperawatan di Rumah Sakit Medan. Universitas Sumatera Utara; 2016.

Jamshidi, L. (2012). Tantangan dari Pengajaran Klinis dalam Keterampilan Perawat dan Pembelajaran Seumur Hidup dari Sudut Pandang Mahasiswa Perawat dan Pendidik. Procedia - Ilmu Sosial dan Perilaku,46, 33353338.doi:

https://doi.org/10.1016/j.sbspro.201 2.06.062

Kemenkes. Profil Kesehatan Indonesia 2016. Jakarta: Kemenkes;

Mauidlotul Alifah. "Hubungan Persepsi Mengenai Pembimbingan Klinik terhadap Pencapaian Kompetensi Klinik Mahasiswa Keperawatan". Tahun 2017, Halaman1-8 : http//ejournal-s1.undip.ac.id/

Mulyasa. 2010. Menjadi Guru Profesional (Menciptakan Pembelajaran Kreatif dan Menyenangkan). Bandung Rosda. Cetakan kesembilan.

Mulyawan B. Pengaruh pengalaman dalam pelatihan terhadap peningkatan kompetensi profesional guru. ejournal Univ Pendidik Ganesha. 2013;45-65.

Musfah,Jejen. (2011). Peningkatan Kompetensi Guru: Melalui Pelatihan dan Sumber Belajar Teori dan Praktik. Jakarta: Kencana.

Ngesti W. Utami. (2018) Pencapaian Kompetensi Asuhan Keperawatan dengan Menggunakan Modul Praktikum Bedside Teaching dan Penugasan Mahasiswa Keperawatan. Poltekkes Kemenkes Malang, Jl. Besar Ijen No 77 C Malang

Notoatmodjo, S. (2012) Metodologi Penelitian Kesehatan. Jakarta: Rineka Cipta. https://doi.org/10.1590/S1516- 
18462008000300012

Notoatmodjo, S. 2010. Metodologi Penelitian Kesehatan. Jakarta : Rineka Cipta.

Nursalam (2011) Manajemen Keperawatan-Aplikasi dalam Praktek Keperawatan Profesional. 3 ed. Jakarta: SalembaMedika.

Nursalam, (2012). Konsep Penerapan Metodologi Penelitian Ilmu KeperawatanPedoman Skripsi, Tesis Dan Instrumen Penelitian Keperawatan. Jilid I.Jakarta : Salemba Medika.

Peraturan Pemerintah Republik Indonesia Nomor 93 Tahun 2015

Peraturan Presiden No. 8 Tahun 2012

RR Viantika Kusumasari. "Penerapan Preceptoship Model terhadap Kompetensi dan Performance Assessment Model Approach". Jurnal Ilmiah Ilmu Keperawatan dan Ilmu Kesehatan. Volume 12. No. 1 Januari 2017; Surya Medika

Sari, SM, Ennimay, Marni, E., \& Anggreny, Y. (2016). Implementasi Preceptorship Model Memperbaiki Pencapaian Kompetensi Mahasiswa Klinik Perawat (Implementasi Model Preceptorship Meningkatkan Pencapaian Kompetensi Mahasiswa Profesi Ners). Jurnal INJEC, 2 ( 1), 118-125.

Setyaningsih, M, Felisitas, \& Maria Prieska P, 2016, Pengaruh Metode Mentorship Perawat Terhadap Kemampuan Caring Mahasiswa, Jurnal Ilmu Kesehatan Vol.4 No.2.

Setyobudi I, Martono. Pencapaian kompetensi penilaian glasgow coma scale dengan metode beside teaching mahasiswa program DIII berlanjut DIV keperawatan. J Ilmu Kesehat. 2013;2(2):118-22.

Sugiyono. 2011. Metode Penelitian Kuantitatif, Kualitatif dan R\&D. Bandung: Afabeta

Sujarweni, V. Wiratna. 2014. Metode
Penelitian: Lengkap, Praktis, dan Mudah Dipahami. Yogyakarta: Pustaka Baru Press.

Sukihananto. Hubungan dokumentasi keperawatan berbasis komputer dengan daya berpikir kritis perawat pada pelaksanaan proses keperawatan di RSUD Banyumas. Universitas Indonesia; 2010.

Undang-Undang Nomor 38 Tahun 2014. Tentang Keperawatan. Disahkan di Jakarta tanggal 17 Oktober 2014. Presiden Republik Indonesia, DR. H. Susilo Bambang Yudhoyono. 